\title{
Temporary and Regular Workers Fulfill Their Tasks Side-by-Side, But in Different Learning Conditions ${ }^{1}$
}

\author{
Gunnar Augustsson ${ }^{2}$ \\ Department of Education \\ Mid Sweden University \\ Härnösand \\ Sweden
}

Purpose. The purpose of this study is to identify temporary workers' (temps') expected conditions for learning when they are leased to a client company (CC) for numerical flexibility.

Design/methodology/approach. The analysis is based on a phenomenological approach containing 121 transcribed interviews with employees and managers who were active in more than 10 CCs' in seven industries and from seven temporary work agencies.

Findings. One important finding is that the CC expects temps not to learn something about the surrounding organization, but to limit themselves only to the concrete tasks assigned to them. Another is that temps' opportunities to influence organizational conditions in the CCs seem to be cut off in a strategic way.

Research limitations/implications. Results are valid for interviewees' expressed thoughts and expectations about temps' workplace learning, not about an actual separation between knowledge and actions in the working conditions.

Practical implications. CCs associate temps with learning backgrounds that allow them to perform subordinate tasks, such as routine, instructional, or regulatory duties. They associate regular staff with more advanced learning backgrounds and tasks more directly related to occupation and workplace. CCs could benefit from accepting the exchange of knowledge and competence between temps and the company, rather than neglecting it.

Social implications. Many temps work side-by-side with regular employees while they often engage in limited areas of the CCs' organization.

Originality/value. The originality of this paper lies in its contribution to the relatively unexplored topic of workplace learning and leaders and employees' expectations of temps.

Keywords: adaptation, client company, development, interorganization, learning, temporary work(ers)

Article type: Research paper

\section{Introduction}

A number of studies have highlighted the social differences between temporary and regular staff, emphasizing workplace alienation (Garsten, 1999) or exclusion (Augustsson and Olofsdotter, 2008). This paper analyzes temporary workers' (temps') workplace learning conditions. Importantly, such analysis shows the preconditions for exchange of skills between temps and regular workers. This is a relatively unexplored topic: most research on temping so

1 Augustsson, G. (2014) “Temporary and Regular Workers Fulfill Their Tasks Side-by-Side, But in Different Learning Conditions”. Journal of Workplace Learning, Vol. 26, No. 2, pp. 79-90.

2 The author would like to thank The Swedish Council for Working Life and Social Research (FAS) and The Swedish Governmental Agency for Innovation Systems (VINNOVA), which funded the studies reported in this paper. FAS funded the studies from 2004 (Dnr 2002-0208) and 2008 (Dnr 2006-0880), and VINNOVA funded the study from 2010/2011 (Dnr 2009-03060). The funders did not have any influence on the research after they approved funds for each study. The author also would like to thank his colleagues Lena Boström, Associate Professor, Ph. D., Jimmy Jaldemark, Ph. D., Gunilla Olofsdotter, Ph. D., and Lena Randevåg, M. Ph., and two anonymous reviewers from the journal for their critical but constructive comments on drafts of the manuscript. 
far has primarily concerned temps' disposability (see for example Atkinson, 1984; Boyce et al., 2007; Burgess and Connell, 2006; Degiuli and Kollmeyer, 2007; Garsten , 2004), not about the mutual learning relationship a client company (CC) expects with its temps as shown in Jooste and Prinsloo (2013). Garsten (2004) underlines the importance of temp learning and Jooste and Prinsloo (2013) give attention to the need of deeper knowledge exchange between a CC's specific setting and the temp in question. A combination of their results reveals a gap in knowledge worth filling by looking more closely at leaders and employees' expectations of temps. This is the paper's aim.

A CC leases temps to increase its numerical flexibility, its ease of increasing or decreasing the number of employees or working hours in its organization in the short and long terms (Atkinson, 1984, 1987). Our analysis took an interorganizational perspective, using temps from one temporary workers' agency (TWA) (Augustsson et al., 2010; Grimshaw and Rubery, 2005). "Client company” means a "natural or legal entity that from employment agencies rents workers for temporary work at a customer company under its control and authority" (SOU, 2011:5, p. 31). The unit of analysis consists of the knowledge and actions CCs expected temps to master: what the temp offered the CC and what the CC requested.

The paper begins with a brief literature review on temporary work. This is followed by sections on theory of learning, methods, results, discussion, and conclusions.

\section{Previous Research about Temporary Work}

Companies have various motives for using temps (Burgess and Connell, 2006; Stanworth and Druker, 2006). They may need specific knowledge or skills (Alvesson and Robertson, 2006; Bergström et al., 2007) or may need temps to perform duties the regular staff could perform but lacks the time to do so (Atkinson, 1984; Carey, 2011; Forde et al., 2008; Hall, 2006). This paper regards the latter need. Such temps are, however, expected to work in fields with very different qualifications, ranging from medicine to welding.

Temps are expected to adapt to CCs' needs of academic, social, and practical skills. To be successful, they need the "ability to learn, to communicate, to cooperate, to judge one's own situation, to make diagnoses, to understand and embrace change, as well as mobility" and "continuous learning and upgrading of skills" (Garsten, 2004, p. 163).

The causes for staffing can affect temps' integration into the CC (Håkansson and Isidorsson, 2012). Temps hired to increase numerical flexibility are more likely to be integrated and compensated on par with regular employees than those hired to minimize costs (Connelly and Gallagher, 2004) or perform simple tasks (Håkansson and Isidorsson, 2012).

Studies have shown that staffing can be ambiguous for organizations and individuals (Connelly et al., 2011; Hippel and Kalokerinos, 2012; Galais and Moser, 2009; Jonsson, 2007). For the CC, staffing involves numerical flexibility, increased efficiency, and a complex, heterogeneous workforce and organization (Atkinson, 1984; Burgess and Connell, 2006; Degiuli and Kollmeyer, 2007; Håkansson and Isidorsson, 2012; Jooste and Prinsloo, 2013; Tempest and Starkey, 2004). For the temp, it means a certain variety of commitments and new career opportunities, combined with vulnerability in relation to contracts and negotiations between the TWA and the CC (Degiuli and Kollmeyer, 2007; Håkansson and Isidorsson, 2012; Nienhüser and Matiaske, 2006; Smith, 2010; Tempest and Starkey, 2004).

CCs often want temps to learn (Garsten, 2004) and have a rarely spoken need to select the right temp and to give that temp necessary preconditions for a good job (Jooste and Prinsloo, 2013). This makes it crucial to better understand the learning context employees and managers in CCs require for temps. What competence is and is not welcomed in a CC? The answer may shed light on social differences between temps and regular staff. 


\section{Theory}

There are two relevant theoretical aspects in interorganizational relations: power relations in between-group relationships and learning. Power relations between groups involve a (staff) group’s “ability and capacity for integration and cohesion among group members" and are "the basis for the group's position of power" (Olofsson, 1999, p. iii). A group's cohesion is therefore a power resource when its members raise the group's limits in relation to members of other groups (Boyce et al., 2007; Carey, 2011).

Learning in work organizations affects people's knowledge, skills, thoughts, attitudes, interpersonal relations and, last but not least, communication (Ardenfors and Lindvert, 2011; Ellström, 1992, 1996; Ellström et al., 2005; Illeris, 2009; Svensson, 2009). Different environments can stimulate or discourage different types of workplace learning (Ellström et al., 2005; Illeris, 2009; Svensson, 2009). Such learning backgrounds characterize the social order of learning in connection to staff hiring.

This study splits learning into two dimensions: knowledge and action (Ellström, 1996). "Knowledge” means ideas, insights, or fairly firm opinions. "Action” refers to any form of expression. Knowledge is primarily a mental phenomenon, which the learner may not express to others. Action is expressed or practiced knowledge perceptible to others. It can be misleading to separate the two, but our motive for doing so lies in discovering interviewees' thoughts on a possible difference, not trying to prove a real difference.

We will use Ellström's (1996) dimensions to conceptualize the expectations of knowledge and actions associated with agency staff: they describe expected knowledge along a continuum from being unreflective to being reflective in relation to a position or duties. This allows a focus on limiting learning to what concerns and does not concern temps in the CCs. CCs' expectations are compatible with what Gustavsson (2007) writes about “opportunities” for learning among operators in industrial work.

\section{From Unreflective to Flexible, Reflective Use of Knowledge}

The knowledge that an individual has can be enough, more, or less than that required for a specific or work task. It is within the relationships of the individual, the worker's skills, and the work to be done that the concept of competence arises. A person whose skills are in line with the current work can be perceived as competent, that is, the worker's knowledge is sufficient.

Ellström (1996) identified four different knowledge levels in relation to a position or tasks. At the lowest level is no explicit requirement of knowledge from the individual. Knowledge is perceived as implicit, "unreflected.” The next level involves knowing "procedures" (Ellström, 1996). This knowledge makes it possible to establish a rule and knowing which rules apply and when. The third level of knowledge is more theoretical, a "conscious analytical thinking," based on goals, "reflections on past experience," and context (Ellström, 1996, p. 30). This type of knowledge is integrated within relatively well-organized thought patterns, so-called schemata or mental models. It is necessary to formulate goals, intentions, and relevant action plans. Ellström (1996) calls the fourth and final level of knowledge "metacognitive" (p. 31). The individual who can relate metacognitively maintains reflexive distance, knows how to "think in alternative terms," and can analyze various conditions (Ellström, p. 31).

\section{From a Routine Basis to Individual Behavior}

The expectations on an individual within a position or work tasks should depend on the individual's level of knowledge. Ellström (1996) reported four levels of action associated with the aforementioned knowledge levels. However, there is a relative independence 
between knowledge and action. A worker may hold one level of knowledge but act on any of the other action levels.

The first level corresponds to low demand for conscious control over work performance (Ellström, 1996). It refers to the ability to perform actions based on routines. The second level requires workers to follow various procedures and "rules of thumb" and to "identify and interpret observations of events in the environment" (Ellström, p. 30). The third level represents knowledge-based actions that need workers "to identify, interpret and evaluate information and feedback from previous actions” (Ellström, p. 30). More specifically, it involves the ability to apply knowledge or theories to unfamiliar situations that call for problem solving. On the fourth and final level, the individual faces expectations about a highly individual approach, reflective action (Ellström, p. 31). This implies recurrent, continuous and evaluative reflections on some tasks "based on the business's goals and underlying values and analysis of one's own actions” (Ellström, p. 31).

Overall, the four action levels form a continuum of expectations from being able to act without thinking first and needing to think first and act afterward.

Based on the above, we can analyze expectations on temps' commitments in a CC in terms of learning focus and learning backgrounds.

\begin{tabular}{|c|c|c|c|}
\hline $\begin{array}{l}\text { Learning } \\
\text { focus }\end{array}$ & $\begin{array}{l}\text { Learning } \\
\text { backgrounds }\end{array}$ & Knowledge levels & Action levels \\
\hline \multirow[t]{2}{*}{ Contextual } & \multirow[t]{2}{*}{$\begin{array}{l}\text { Development } \\
\text { oriented }\end{array}$} & $\begin{array}{l}\text { Distance, alternate, } \\
\text { analyze }\end{array}$ & $\begin{array}{l}\text { Reflect on the basis of goals, } \\
\text { values, and actions }\end{array}$ \\
\hline & & Theoretical knowledge & Knowledge-based behavior \\
\hline \multirow[t]{2}{*}{ Cognitive } & \multirow[t]{2}{*}{ Adaptive oriented } & $\begin{array}{l}\text { Knowledge of rules and } \\
\text { procedures }\end{array}$ & Rule-based behavior \\
\hline & & $\begin{array}{l}\text { Unreflective } \\
\text { knowledge }\end{array}$ & Routine-based behavior \\
\hline
\end{tabular}

Ellström's (1996) analytical model in Matrix 1 divides learning focus into two complementary dimensions: cognitive and contextual. The former involves expectations of employees' mental capacity, and the latter involves the organizational context. The cognitive learning focus is adaptive, corresponding to know-how and unreflective knowledge, with the actions of following procedures and rules and doing routine work. The contextual learning focus is developmental: corresponding to distanced and analytical skills and theoretical knowledge, with the actions of reflecting on the basis of goals, values, and actions, applying theory and evaluating results.

This paper argues that the division between cognitive and contextual focuses and their connection to different learning backgrounds represents a division between different staff groups. Thus, regardless of their knowledge and action levels, individuals from different staff groups will be associated with different learning backgrounds.

\section{Method}

This paper was built on an analysis of 121 transcribed interviews with people active in more than $10 \mathrm{CCs}$ in seven industries (health care, social services, telecommunications, customer service, metal processing, administration, and logistics). The interviewees from TWAs came from seven agencies.

The interviews have been collected in three research projects over seven years. Twenty-two are from 2004, 82 are from 2008, 10 are from 2010, and 7 are from 2011. Sixty- 
three of them come from CCs (26 with managers and 37 with employees). Fifty-eight come from TWAs (10 with managers and 48 with employees). An important consequence of using such widely collected data is that some information is too time-specific or organizationspecific for comparison, while other information is general enough to be used in a complementary way. We examined only the information that told us something about learning related to the social relationships between CCs' leaders, regular personnel and temps. This approach illuminated the combination of pedagogical aspects of learning and sociological aspects of power between the two staff groups, temps and regulars. Timespecific and organization-specific aspects are put aside.

We selected most interviewees in a similar way, by contacting a TWA, which led to direct contact with a key member of the CC. This contact took on or delegated the task of selecting interviewees. When we contacted both, we expressed a desire to interview people with at least one year of experience in their roles, as manager, temp, or ordinary staff. None of the projects allowed us to anticipate the number of interviewees more than three days before arrival. Also, we could not select interviewees, because their availability varied with day-to-day workload. We did most interviews in special rooms at the TWA or the CC. With a few exceptions, we have followed up on interviewees' tips on additional interviewees.

The interviews were semi-structured: the questions were not exactly the same for each interviewee. Instead, we encouraged interviewees to talk freely and casually about their experiences of different aspects of temporary staffing-more about some, less about others. Conversational topics included expectations of individuals from different personnel groups, such as behavior in general, attitude about work purposes and objectives, learning conditions, cooperation between temps and regulars, both groups' treatment of managers and leaders, and acceptable behavior in relation to work, colleagues and managers. In all cases, we followed up answers to interview questions with such questions as "Can you give an example?” "What do you mean?” and “Can you develop your answer?” (Sandberg, 2005). The questions varied depending on whether the interviewees were subordinates, middle managers, senior managers, or union representatives, but their significance was the same. All interviews were recorded and took between 35 and 75 minutes, averaging 50 to 60 minutes.

The interviews covered what Berg Sørensen (1988) terms composite phenomena, individual phenomena, objects, individual actions, and symbols. They were linked to the organization as a whole and issues associated with specific departments, locations, and action sequences. The aim was to cover structural phenomena, what is going on between people at work, and how this might influence rules and resource allocations in the structure. Data analysis helped identify temporary workers' conditions for learning, as did deduction from the knowledge and action levels in Matrix 1. Interview analysis yielded 114 statements, with information corresponding to the analysis model. When interpreting them, we took care to keep all information in a meaningful context.

An important implication of the fact that the study is based on interview data is that the results are about the interviewees' thoughts about each organization (Silverman, 1993). They highlight what the interviewees talked about and how they presented their ideas. Conclusions can therefore be drawn about the interviewees' thoughts, but not about an actual separation between knowledge and actions.

All analyses used hard copies of taped interviews. Interviewers were sometimes and sometimes not the later analysts of their respective interviews. Transcribers were a separate group entirely. However, the author analyzed the interviews.

The interviewed were coded to make it possible to see the variations in the following categories: year of the interview (2004, 2008, 2010, or 2011); individual number; public (pub) or private (pri) organization; workers in the client company (cc) or temporary work agency (twa); and status: employees (emp), leader (lead), manager (man), or union 
representative (uni). The code "08/63, pri, cc, emp” means the interview was conducted in 2008 with individual No. 63, a private client company subordinate employee. Interviews from 2004 used pseudonyms instead of individual numbers. The coding increased the credibility of the results by accurately showing who said what.

In order to ensure the study's validity and reliability, we used Sandberg's (2005) "phenomenological epoché" strategy (p. 59). The researcher has tried to avoid his own theories and prejudices when interpreting and analyzing statements, and instead highlights the interviewees. The strategy includes paying attention to variations and complex circumstances; describing rather than explaining interviewees' experiences and perceptions; considering all aspects mentioned as equally important; searching for fundamental and meaningful structures; and searching for correlations in interviewees' intentions and utterances. The interviewees' responses were collected, transcribed, and analyzed in a systematic manner with other anonymous interviewees, within and between each staff.

The approach has compared data with the analytical model in Matrix 1 without forcing data into it. The goal has been to let the data "speak for itself" as much as possible. We have analyzed data and results from 2004 in collaboration with a colleague while checking 2008, 2010, and 2011 data and results with leaders from various TWAs. We also checked the later two years with leaders at a client company. No one suggested that any amendments or refinements be made to the findings or conclusions.

\section{Results}

The analysis begins by distributing selected interview quotes under Ellström's (1996) action-theoretical frame of reference (Matrix 2 below). Then we analyze the quotes, progressing through Ellström's levels of knowledge.

\section{Matrix 2: The distribution of all 114 quotations based on Ellström's (1996) action- theoretical frame of reference (\% given in parentheses).}

\begin{tabular}{l|l|l|l}
$\begin{array}{l}\text { Learning } \\
\text { focus }\end{array}$ & $\begin{array}{l}\text { Learning } \\
\text { backgrounds }\end{array}$ & $\begin{array}{l}\text { Knowledge levels (50 } \\
\text { \%) }\end{array}$ & Action levels (50 \%) \\
\hline Contextual & $\begin{array}{l}\text { Development } \\
\text { oriented (27\%) }\end{array}$ & $\begin{array}{l}\text { Distance, alternate, } \\
\text { analyze }\end{array}$ & $\begin{array}{l}\text { Reflect on the basis of goals, } \\
\text { values, and actions }\end{array}$ \\
\cline { 3 - 4 } & Theoretical knowledge & Knowledge-based behavior \\
\hline Cognitive & $\begin{array}{l}\text { Adaptive oriented } \\
(73 \%)\end{array}$ & $\begin{array}{l}\text { Knowledge of rules } \\
\text { and procedures }\end{array}$ & Rule-based behavior \\
\cline { 3 - 4 } & $\begin{array}{l}\text { Unreflective } \\
\text { knowledge }\end{array}$ & Routine-based behavior \\
\hline
\end{tabular}

The 121 transcribed interviews yielded 114 statements, with $73 \%$ referring to cognitive, adaptive learning focus and $27 \%$ to contextual, developmental focus. These percentages show an emphasis on adaptive expectations in temping. Statements about knowledge levels divided into unreflective knowledge at 20\%, knowledge of rules and procedures at $18 \%$, theoretical knowledge at $12 \%$, and distance, alternates, and analysis at $0 \%$. Action levels divided into routine-based behavior at $19 \%$, rule-based behavior at $16 \%$, knowledge-based behavior at $15 \%$, and reflecting on goals, values, and actions at $0 \%$.

Although the collected data contains many more quotes that reflect our analytical model presented above, for reasons of space, we only list the most concrete statements here. 
The cognitive learning focus is characterized by an expectation of employee adaptation to "the sum of the abilities of the individual ... that lead to successful performance of the given, not of individual self-defined, data and methods" (Ellström, 1992, p. 27).

The following two quotations underline that the temps' contribution first of all involves unreflective knowledge. The first quote suggests a person hired primarily to do something and not think so much: "One can set different requirements depending on whether it is a temporary or a regular employee. Temp, then you should only run on" (10/34, pub, cc, man). The next quote shows this expectation from temps is anchored in the surrounding organization: "People all the time saying 'you do not need to be on this, you do not need to hear this' and so on. One can feel very excluded like that” (11/37, pub, twa, emp).

This implies a routine-based behavior where the individual and task are matched with one another optimally so that nothing need be changed about either. One employee confirms this: "It feels like temps do not have as much influence. They should do as they're told" (08/10, pri, cc, emp). One temp agrees and adds that this applies to her despite a higher academic qualification than her current work tasks requires: "Yes actually I do not get MBA assignments, which I as an MBA can do. I always get that kind of assistant assignments" (04/Madina, priv, twa, emp).

Therefore, learning for adaptation represents a reactive strategy with respect to the individuals' approach to their working conditions. A manager explained it in terms of knowledge of rules and procedures:

It's the regular doctors who are sent on training and that have additional commitments at the health center. The rented doctors do not do that ... My view is that they shall work, do their jobs when they are here (10/34, pub, cc, man).

Under normal circumstances, even a temp doctor's work tasks are mostly about rules concerning the organizational order. This means that, as the next quote shows, temps must be well prepared before arriving at the CC:

With outsourcing it has become more about skills. If I want a person I want to have the right skills, the right conditions and the right attitude (08/24, priv, cc, man).

Rule-based behavior is the result of instructions, conclusions from past experience, or solutions to problems from concrete situations within the actual organization:

You have to be very responsive and able to adapt to different conditions, different types of people... That you silently may blend in, so as not to stick up. (04/Magda, pri, twa, emp)

Temps are expected to blend into the existing organization, for several reasons: "As hired, you must show commitment. I guess temps are more involved or play that role in any case, because they have to be able to stay" (08/60, pri, twa, emp).

These last quotes underline temps' sense of alienation, which other researchers have covered (Garsten, 1999). The quotes in this section show that CCs expected temps to perform their tasks without any reflections or deeper knowledge about organizational context, matching Ellström's (1996) two lowest knowledge and action levels. Whoever performs tasks for adaptation will find their mental and physical autonomy limited.

Learning for Development—an Active Approach 
The developmental, contextual learning focus is based on enabling individuals "to influence and change their working and living conditions” (Ellström, 1992, p. 27).

Theoretical knowledge helps assess predictions about future actions or events on the job. But temps are not included in the construction of that kind of prediction:

The nurse that I have, the first thing she did was to comment on how the job was handled here, and I could really just agree with her, but I did not ... I could agree with her views, but stressed that she was hired here, and then you have to adapt to the rules and guidelines that apply here ... (10/34, pub, cc, man)

As Ellström (1996) would say, temps are excluded from a natural ambition to engage their working conditions theoretically, or therefore approach them actively. They are only expected to contribute well-defined, non-theoretical tasks:

We have manual welders and we have the robot operators. We have never hired any robot operators ... But we have fixed manual welders and it is them we have been renting, mostly. (08/24, pri, cc, man)

We have hired a doctor fairly recently ... that is supposed to be the one who is medically responsible and gathers the doctors. That person will of course eventually get a little bit different tasks compared to what our hired doctors have. (10/06, pri, cc, emp)

In short, learning development as an active approach is not applicable to temps because only ordinary staff are allowed to relate the individual elements of a position or task into an integrated organizational whole. Temps are cut off from any real influence in the organization, or from garnering such powers that arise from the profession and duties:

Right now I would, for example, need to make decisions in a lot of cases, and there is no one who has shown me how to make a decision, so I do not know how to do it. (11/37, pub, twa, emp)

Temp doctors should not distance themselves from their immediate tasks or analyze them, which means that temp doctors are "not engaged in organizational development, so what they should do is take care of patients, nothing else" (10/08, pub, cc, man). Therefore:

They do not have to think so much about what is around them, because they are not on staff meetings or anything like that. They are a little bit on the side ... (10/33, pub, cc, emp)

Nor should they reflect on goals, values, or actions. Nor should they participate in discussions of the work tasks or the organization: "We have a couple of hired doctors who have been with us for years, but they never really participate in the [weekly medical] meetings” (10/33, pub, cc, emp). “Trade union meetings and such ... Telecom's regular personnel are paid to go those meetings, but not the temps” (08/8, pri, cc, emp).

Temps, in short, should perform their duties within assigned, routine-based limits and not engage in the organization at large. There is no desire for temps to apply mental flexibility between existent organizational circumstances and their possible alternatives.

The CC does not expect temps to orient themselves in the surrounding organization or learn anything, only to focus on their concrete tasks or, at most, follow some rules. More 
developmental learning is intended for the regulars. Temps' opportunities to influence a CCs' organizational conditions are cut off in a strategic way.

\section{Discussion and Conclusions}

This paper dealt with temps' conditions for learning when their work was leased to a CC. Knowledge of such conditions may help develop and streamline collaboration between TWAs and CCs and increase the efficiency of CCs' orders. Many temps work side-by-side with regular employees but engage in limited parts of the CC's organization and operate under different organizational conditions than the CC’s regular staff (Håkansson and Isidorsson, 2012). Thus, this study could not identify differences between positive and negative learning features on both individual and organizational levels that Tempest and Starkey (2004) describe.

The data used Ellström's framework $(1992 ; 1996)$ to distinguish between expected and unwanted learning backgrounds in the interpretations of the interviewees' statements, to distinguish an adaptation-oriented from a development-oriented background, and highlight the social order of learning in the studied CCs.

In the adaptation-oriented background, individual and task are optimally matched so that the CC can adapt temps to a limited part of the organization. This allows the CC the work of unique individuals and offers the temp limited autonomy and a reactive approach to the part of the organization beyond the current job (Hall, 2006). Temps belong to a "themgroup," expected to abide with prevailing circumstances. This is reflected in the differences between temporary and regular staffs' learning focuses. CCs expect temps to perform their duties within specified adaptive parameters, without too much awareness about the surrounding organization. Connelly et al. (2011) show how such a strategy can be counterproductive for both the TWA and the CC.

The development-oriented learning background implies a proactive organizational commitment, which does not apply to agency staff, only regular employees. In this activity, there are no watertight compartments between the employee's tasks and the surrounding organization. Employees belong to a "we-group," in which regulars broaden their intellectual and practical knowledge about and within the company. The social order relevant to regulars is a location-based social and organizational community.

\section{Conclusions}

This study has three main conclusions. The first is that organizational subordination and superordination develop where agency staff members are associated with different learning backgrounds. The second conclusion is that as soon as the issue of more advanced learning backgrounds and tasks arise, CCs rely on their regular staff. Thus, the temps and regular staff often work side-by-side but in different learning backgrounds, implying little knowledge exchange between them (cf. Nesheim et al., 2007). The final conclusion is that CCs use temps not only to allow numerical flexibility but to stabilize themselves and protect the organization in a way that guarantees regular staff members' internal involvement but not the temps'. CC managers do not distinguish between hiring a resource or expertise and hiring a person.

Current working conditions tend to be characterized more by intergroup relationships than by optimal functionality, which makes an intragroup mentality dominate over professionalism and individuality. Although CCs usually does not associate temps with learning, special circumstances may challenge this practice. Hiring costs are high and use of temporary doctors and nurses is limited. Temps bring knowledge and skills more or less unnoticed into and out of CCs. They are valuable resources that CCs are wasting. 
This implication invites reflections on future research on why CCs do not integrate temps. Is it an overly instrumental view of temps' used? Is it because of cultural differences in some businesses or professions? Is it because CCs fear losing knowledge or criticism from their regular staff? Is it due to a fear of competition or an idea of appropriate relationships between different groups of staff? An important future object of study should be cultural differences among professions: motives for knowledge transfer between temporary and regular doctors may have a different priority than between temporary and regular welders.

These results are valid for temps performing practical work and not for temps who only contribute their expertise. It does not matter if the temps have higher education as doctors or lower education as welders. The results apply to their practical contribution to the CC's business. The results also apply to CCs in a particular location.

This study has two important overall limitations. One is that data from 2004 and 2008 were not primarily collected to study learning expectations among temps. The purpose of these studies was studying temps' working conditions in general, with learning only one dimension of them. Another limitation is that interviewee samples represent different times and businesses. We were not able to follow interviewees within the same business over time.

However, the study's validity and reliability within the qualitative paradigm were addressed in several ways. We have systematically and anonymously obtained and analyzed the interview data and engaged in peer review of the data and results with a colleague, leaders from various TWAs, and leaders at a CC.

\section{References}

Alvesson, M. and Robertson, M. (2006), “The best and the brightest: The construction, significance and effects of elite identities in consulting firms”, Organization, Vol. 13 No. 2, pp. 195-224.

Ardenfors, M. and Lindvert, J. (2011), “Kompetensutveckling —ett tomt erbjudande”, in C. Garsten, J. Lindvert, and R. Thedvall (Eds.), Arbetets marknad: arbetsmarknadens nya organisering, Liber, Malmö, pp. 210-229.

Atkinson, J. (1987). "Flexibility or fragmentation? The United Kingdom labour market in the eighties”, Labour and society, Vol. 12 No. 1, pp. 87-105.

Atkinson, J. (1984), “Manpower strategies for flexible organisations”, Personnel Management, August, pp. 28-31.

Augustsson, G., and Olofsdotter, G. (2008), “Uthyrda konsulter från bemanningsföretag: Främling eller outsider?”, Arbetsmarknad \& Arbetsliv, Vol. 14 No. 4, pp. 11-25.

Augustsson, G., Olofsdotter, G. and Wolvén L-E., (2010), Swedish managers in TWA act as boundary spanners, Leadership \& Organization Development Journal, Vol. 31 No. 1, pp. 4-17.

Berg Sørensen, T. (1988), Fænomenologisk mikrosociologi: interview-og samtaleanalyse 1, (1. udg.), Forl. Gestus, Århus.

Bergström, O., Håkansson, K., Isidorsson, T. and Walter, L. (2007), Den nya arbetsmarknaden-Bemanningsbranschens etablering i Sverige, Academia Adacta, Lund.

Boyce, A. S., Ryan, A. M., Imus, A. L. and Morgeson, F. P. (2007), “Temporary worker, permanent loser? A model of the stigmatization of temporary workers”, Journal of Management, Vol. 33 No. 1, pp. 5-29.

Burgess, J. and Connell, J. (2006), “Temporary work and human resources management: Issues, challenges and responses”, Personnel Review, 35 No. 2, pp. 129-140.

Carey, M. (2011), "Here today, gone tomorrow? The ambivalent ethics of contingency social work”, Critical Social Policy, Vol. 31 No. 4, pp. 540-561. 
Connelly, C. E. and Gallagher, D. G. (2004), “Emerging trends in contingent work research”, Journal of Management, Vol. 30 No. 6, pp. 959-983.

Connelly, C. E., Gallagher, D. G. and Webster, J. (2011), "Predicting temporary agency workers' behaviors: Justice, volition, and spillover”, Career Development International, Vol. 16 No. 2, pp. 178-194.

Degiuli, F. and Kollmeyer, C. (2007), "Bringing Gramsci back in: Labor control in Italy’s new temporary help industry”, Work Employment Society, Vol. 21 No. 3, pp. 497515.

Ellström, P-E. (1992), Kompetens, utbildning och lärande i arbetslivet: Problem, begrepp och teoretiska perspektiv, Publica, Allmänna förlaget, Stockholm.

Ellström, P-E. (1996), Arbete och lärande: Förutsättningar och hinder för lärande i dagligt arbete, Arbetslivsinstitutet, Solna.

Ellström, P-E., Löfberg, A. and Svensson, L. (2005), "Pedagogik i arbetslivet: Ett historiskt perspektiv”, Pedagogisk forskning i Sverige, Vol. 10 No. 3/4, 162-181.

Forde, C., MacKenzie, R. and Robinson, A. (2008), "Help wanted? Employers' use of temporary agencies in the UK construction industry”, Employee Relations, Vol. 30 No. 6, pp. 679-698.

Galais, N. and Moser, K. (2009), “Organizational commitment and the well-being of temporary agency workers: A longitudinal study”, Human Relations, Vol. 62 No. 4, pp. 589-620.

Garsten, C. (1999), "Betwixt and between: Temporary employees as liminal subjects in flexible organizations”, Organization Studies, Vol. 20 No. 4, pp. 601-617.

Garsten, C. (2004), "Be a Gumby: The political technologies of employability in the temporary staffing business”, in Garsten, C. and Jacobsson, K. (Eds.), Learning to be employable. New agendas on work, responsibility and learning in a globalizing world, Palgrave McMillan, New York, pp. 152-171.

Grimshaw, D. and Rubery, J. (2005), "Inter-capital relations and the network organisation: redefining the work and employment nexus”, Cambridge Journal of Economics, Vol. 29 No. 6, pp. 1027-1051.

Gustavsson, M. (2007), “The potential for learning in industrial work”, Journal of Workplace Learning, Vol. 19 No. 7, pp. 453-463.

Hall, R. (2006), “Temporary agency work and HRM in Australia: Cooperation, specialisation and satisfaction for the good of all?” Personnel Review, 35 No. 2, pp. 158-174.

Hippel, C. V. and Kalokerinos, E. K. (2012), "When temporary employees are perceived as threatening: antecedents and consequences", Leadership \& Organization Development Journal, Vol. 33 No. 2, pp. 200-216.

Håkansson, K. and Isidorsson, T. (2012) "Work organizational outcomes of the use of temporary agency workers”, Organization Studies, Vol. 33 No. 4, pp. 487-505.

Illeris, K. (2009), Competence, learning and education: How can competences be learned, and how can they be developed in formal education?, in K. Illeris (Ed.), International perspectives on competence development: Developing skills and capabilities, Routledge, New York, pp. 83-98.

Jonsson, D. (2007) “Flexibility, stability and related concepts”, in Furåker, B., Håkansson, K. and Karlsson, J. C. (Eds.), Flexibility and stability in working life, Palgrave Macmillan, New York, pp. 30-41.

Jooste, K. and Prinsloo, C. (2013). "Factors that guide nurse managers regarding the staffing of agency nurses in intensive care units at private hospitals in Pretoria”, Curationis, Vol. 36 No. 1, pp. 1-10. 
Nesheim, T., Olsen, K. M. and Kalleberg, A. L. (2007), “Externalizing the core: Firms' use of employment intermediaries in the information and communication technology industries”, Human Resource Management, Vol. 46 No. 2, pp. 247-264.

Nienhüser, W. and Matiaske, W. (2006), “Effects of the 'principle of non-discrimination' on temporary agency work: Compensation and working conditions of temporary agency workers in 15 European countries”, Industrial Relations Journal, Vol. 37 No. 1, pp. 64-77.

Olofsson, G. (1999), “Inför den svenska upplagan 1999”, in Elias, N. and Scotson, J. L. (Eds.), Etablerade och outsiders: En sociologisk studie om grannskapsproblem, Arkiv, Lund, pp. i-xi.

Sandberg, J. (2005), "How do we justify knowledge produced within interpretive approaches?” Organizational Research Methods, 8 No. 1, pp. 41-68.

Silverman, D. (1993), Interpreting qualitative data: Methods for analysing talk, text and interaction, Sage, London.

Smith, C. (2010), "Go with the flow: Labour power mobility and labour process theory”, in Thompson, P. and Smith, C. (Eds.), Working life: Renewing labour process analysis, Palgrave Macmillan, Basingstoke, pp. 269-296.

SOU 2011:5. "Bemanningsdirektivets genomförande i Sverige: Betänkande”, Statens offentliga utredningar, Fritze, Stockholm, available at: http://www.regeringen.se/sb/d/108/a/159357- (accessed 17 June 2012).

Stanworth, C. and Druker, J. (2006), "Human resource solutions?: Dimensions of employers' use of temporary agency labour in the UK”, Personnel Review, Vol. 35 No. 2, pp. 175-190.

Svensson, L. (2009), “Learning environments of employees in knowledge-intensive company units”, in R. Velde, C. (Ed.), International perspectives on competence in the workplace. Implications for research, policy and practice (2nd ed.), Springer, New York, pp. 159-181.

Tempest, S. and Starkey, K. (2004), "The Effects of liminality on individual and organizational learning”, Organization Studies, Vol. 25 No. 4, pp. 507-527. 